\title{
Analisis Dispute Kode Diagnosis Rumah Sakit Dengan Badan Penyelenggara Jaminan Sosial (BPJS) Kesehatan
}

\author{
Irmawati $^{1}$, Marsum ${ }^{2}$, Monalisa ${ }^{3}$ \\ ${ }^{12}$ Poltekkes Kemenkes Semarang \\ ${ }^{3}$ RSUD Kelet Provinsi Jawa Tengah \\ 1irmachristanto@gmail.com
}

\begin{abstract}
Ina-CBG's tariff-shaped package consists of all components of hospital cost based on costing data and coding of diseases referring to International Classification of Diseases (ICD) compiled by the WHO consisting of 14,500 diagnostic codes and ICD 9 CM 7,500 code action. BPJS Verificators are aware of the coding, clinical pathway and diagnosis of diseases that must be attached with the process of examination of the patient, if it is not appropriate it will be returned to the hospital. The purpose of this research is to know the analysis dispute Code of hospital diagnosis with BPJS Kesehatan. Research survey with a quantitative descriptive method through the study of documentation and the observation checklist is equipped with qualitative data retrieval in RSUD Ungaran Type C Hospital. It uses Total Sampling in August 2018 as much as 67 claims files with dispute code. The results showed most of the claims files returned were the case with classification of Case-Mix Main Groups (CMG) code A (Infectious and parasitic diseases Groups) as much as 35.82\%. Description dispute the diagnostic code by BPJS and the hospital occurs under no specific code conditions, KD code (Key Diagnosis) or SD (Secondary Diagnosis) code is not supported by supporting inspection data, the SD code becomes part or advanced of the Code, code On the suspect diagnosis condition. File completion claims return because the code dispute with the rule code reselection of MB2 as much as $59.70 \%$. The determination of the code should always read again and follow the rules. Medical personnel need to understand that the completeness and consistency in filling medical records is necessary to produce accurate code.
\end{abstract}

Keyword : International Classification of Diseases, Ina-Cbg 's, BPJS Kesehatan

\begin{abstract}
Abstrak
Tarif Ina-Cbg's berbentuk paket yang mencangkup seluruh komponen biaya rumah sakit yang berbasis pada data costing dan coding penyakit mengacu pada International Classification of Diseases (ICD) yang disusun oleh WHO yang terdiri dari 14.500 kode diagnosis dan ICD 9 CM 7.500 kode tindakan. Verifikator dari BPJS mencermati diantaranya coding, clinical pathway dan diagnosis penyakit yang harus dilampiri dengan proses pemeriksaan terhadap pasien, apabila tidak sesuai maka akan dikembalikan kepada pihak rumah sakit. Tujuan Penelitian ini adalah untuk mengetahui analisis dispute kode diagnosis rumah sakit dengan BPJS kesehatan. Penelitian survey dengan metode deskriptif secara kuantitatif melalui studi dokumentasi dan ceklist observasi dilengkapi dengan pengambilan data kualitatif di RSUD Ungaran Rumah Sakit Tipe C. Menggunakan Total Sampling pada bulan Agustus 2018 sebanyak 67 berkas klaim dengan dispute kode. Hasil penelitian menunjukkan sebagian besar berkas klaim yang dikembalikan adalah kasus dengan klasifikasi kelompok Case-Mix Main Groups (CMG) kode A(Infectious and parasitic diseases Groups) sebanyak 35,82\%. Gambaran dispute kode diagnosis oleh BPJS dan rumah sakit terjadi pada kondisi kode tidak spesifik, kode DU (Diagnosis Utama) atau kode DS (Diagnosis Sekunder) tidak didukung oleh data pemeriksaan penunjang, kode DS menjadi bagian atau lanjutan dari kode, kode pada kondisi diagnosis suspect. Penyelesaian berkas klaim pengembalian karena dispute kode dengan reseleksi kode rule MB2 sebanyak 59,70\%. Penentuan kode hendaknya selalu membaca kembali dan mengikuti kaidah-kaidah. Tenaga medis perlu memahami bahwa kelengkapan dan kekonsistensian dalam pengisian rekam medis sangat dibutuhkan untuk menghasilkan kode yang akurat.
\end{abstract}

Kata Kunci: International Classification of Diseases, Ina-Cbg's, BPJS Kesehatan 


\section{Pendahuluan}

Salah satu tugas yang dilakukan oleh BPJS Kesehatan sebagai lembaga sosial masyarakat adalah membayarkan manfaat dan membiayai pelayanan sesuai dengan peraturan jaminan sosial yang telah ditetapkan. Sistem pembiayaan yang digunakan oleh BPJS Kesehatan adalah Sistem Pembayaran pelayanan kesehatan berbasis Casemix Ina-Cbg's (Indonesia Case Base Group's) yaitu merupakan aplikasi yang digunakan untuk pengajuan klaim pembayaran oleh rumah sakit sebagai pemberi pelayanan kesehatan. Case Base Group's adalah cara pembayaran perawatan pasien berdasarkan diagnosis-diagnosis atau kasus-kasus yang relatif sama. Tarif Ina-Cbg's dalam program Jaminan kesehatan nasional (JKN) merujuk pada data costing (biaya) 137 Rumah sakit (RS) Pemerintah maupun RS Swasta. Metode perhitungan biaya menggunakan Sistem Ina-Cbg's yang digunakan oleh Rumah Sakit maupun pihak pembayar (pemerintah selaku pihak BPJS) tidak lagi merinci tagihan berdasarkan rincian pelayanan yang diberikan, tapi ditentukan oleh beberapa data penting diantaranya Kode DRG (Disease Related Group), Lenght Of Stay (LOS), Regional Rumah Sakit, Kualifikasi Rumah Sakit (Rujukan Nasional). Tarif Ina-Cbg's berbentuk paket yang mencangkup seluruh komponen biaya RS yang berbasis pada data costing dan coding penyakit mengacu pada International Classification of Diseases (ICD) yang disusun oleh WHO yang terdiri dari 14.500 kode diagnosis dan ICD 9 CM 7.500 kode tindakan. Besar kecilnya tarif yang muncul dalam software Ina-Cbg's ditentukan oleh kode diagnosis dan tindakan medis yang telah ditetapkan oleh koder rumah sakit. Proses pengajuan klaim dari Rumah Sakit kepada BPJS Kesehatan memiliki tahap verifikasi kelengkapan berkas, administrasi kepesertaan, administrasi pelayanan dan pelayanan kesehatan yang bertujuan untuk menjaga mutu layanan dan efisiensi biaya pelayanan kesehatan bagi peserta BPJS Kesehatan. Apabila dalam proses verifikasi terdapat ketidaksesuaian berkas klaim dengan ketentuan dalam tahap verifikasi maka akan terjadi pengembalian berkas klaim dari verifikator BPJS Kesehatan kepada pihak Rumah Sakit. Apabila masih banyak berkas klaim yang dikembalikan oleh BPJS akan berdampak sangat merugikan terhadap Rumah Sakit karena akan memperlambat proses pembayaran klaim. Hasil penelitian yang dilakukan Irmawati (2016) tentang Faktor-Faktor Penyebab Pengembalian Berkas Klaim Rawat Inap oleh
Verifikator BPJS Kesehatan di RSUD Tugurejo didapatkan bahwa dari 97 berkas klaim yang dikembalikan diketahui bahwa sebanyak 62 berkas (64\%) disebabkan oleh factor pelayanan kesehatan yaitu ketidaksesuaian kode diagnose dan prosesur tindakan pada tagihan klaim.

Tabel 1 : Prosentase Pengembalian Berkas Klaim oleh BPJS di RSUD Ungaran Periode Januari Juli 2018

\begin{tabular}{|c|c|c|c|c|c|c|c|}
\hline \multirow{2}{*}{ Bulan } & \multirow{2}{*}{$\begin{array}{l}\text { Jmlh } \\
\text { Ber- } \\
\text { kas } \\
\text { Kla- } \\
\text { im }\end{array}$} & \multicolumn{2}{|c|}{ Diterima } & \multicolumn{2}{|c|}{$\begin{array}{l}\text { Dikem- } \\
\text { balikan }\end{array}$} & \multicolumn{2}{|c|}{ Total } \\
\hline & & $\mathrm{F}$ & $\%$ & $\mathrm{~F}$ & $\%$ & $\mathrm{~F}$ & $\%$ \\
\hline Januari & 808 & 700 & 86,64 & 108 & 13,36 & 808 & 100 \\
\hline Februari & 649 & 544 & 83,83 & 105 & 16,17 & 649 & 100 \\
\hline Maret & 829 & 715 & 86,25 & 114 & 13,75 & 829 & 100 \\
\hline April & 804 & 707 & 87,94 & 97 & 12,06 & 804 & 100 \\
\hline Mei & 802 & 704 & 87,79 & 98 & 12,21 & 802 & 100 \\
\hline Juni & 639 & 537 & 84,04 & 102 & 15,96 & 639 & 100 \\
\hline Juli & 567 & 475 & 86,25 & 92 & 13,75 & 567 & 100 \\
\hline Total & 5.098 & \multicolumn{2}{|c|}{4396} & 702 & 13,89 & & \\
\hline $\begin{array}{l}\text { Rata- } \\
\text { rata }\end{array}$ & & & & & & & \\
\hline
\end{tabular}

Sumber : data klaim pasien RSUD Ungaran

Tabel 1 diketahui bahwa jumlah berkas klaim yang dikembalikan BPJS dalam bulan Januari sampai dengan Juni 2018 mengalami naik turun, dengan rata-rata pengembalian 13,89\%. Kecenderungan ini perlu mendapat perhatian karena sesuai dengan perencanaan rumah sakit, dalam pengajuan klaim bahwa kondisi pengajuan klaim adalah zero rejected.

Tabel 2 : Prosentase Penyebab Pengembalian Berkas Klaim oleh BPJS di RSUD Ungaran Periode Januari - Juni 2018

\begin{tabular}{|c|c|c|c|c|c|c|c|}
\hline \multirow[t]{2}{*}{$\begin{array}{l}\mathrm{Bu}- \\
\text { lan }\end{array}$} & \multirow[t]{2}{*}{$\begin{array}{c}\text { Kla- } \\
\text { im } \\
\text { yang } \\
\text { di- } \\
\text { kem- } \\
\text { bali- } \\
\text { kan }\end{array}$} & \multicolumn{2}{|c|}{$\begin{array}{c}\text { Ketidak } \\
\text { lengkapan } \\
\text { for-mulir } \\
\text { ber-kas } \\
\text { klaim }\end{array}$} & \multicolumn{2}{|c|}{$\begin{array}{l}\text { Ketidak- } \\
\text { sesuaian } \\
\text { kode } \\
\text { berkas } \\
\text { klaim }\end{array}$} & \multicolumn{2}{|c|}{ Total } \\
\hline & & $\mathrm{F}$ & $\%$ & $\mathrm{~F}$ & $\%$ & $\mathrm{~F}$ & $\%$ \\
\hline Januari & 108 & 15 & 13,89 & 93 & 86,11 & 108 & 100 \\
\hline Februari & 105 & 12 & 11,43 & 93 & 88,57 & 105 & 100 \\
\hline Maret & 114 & 31 & 27,19 & 83 & 72,81 & 114 & 100 \\
\hline April & 97 & 22 & 22,68 & 75 & 77,32 & 97 & 100 \\
\hline Mei & 98 & 15 & 15,31 & 83 & 84,69 & 98 & 100 \\
\hline Juni & 102 & 20 & 19,61 & 82 & 80,39 & 102 & 100 \\
\hline Juli & 92 & 14 & 15,22 & 78 & 84,78 & 92 & 100 \\
\hline
\end{tabular}




\begin{tabular}{llll}
\hline Total & 624 & 115 & 509 \\
\hline Rata- & & 18,35 & 81,64 \\
Rata & & & \\
\hline
\end{tabular}

Sumber : data klaim pasien RSUD Ungaran

Tabel 2 diketahui bahwa alasan pengembalian berkas klaim oleh BPJS dari bulan Januari sampai dengan Juni 2018, sebagian besar adalah karena ketidaksesuaian koding dengan rata-rata $81,64 \%$ dan ketidaklengkapan formulir dengan rata-rata $18,35 \%$. Berdasarkan latar belakang diatas, peneliti tertarik melakukan kajian mendalam tentang Dispute Kode diagnosis rumah sakit dengan BPJS Kesehatan.

\section{Metode}

Jenis penelitian ini adalah penelitian survey dengan metode deskriptif yang bertujuan untuk menyajikan gambaran lengkap dengan cara mendeskripsikan sejumlah variabel yang berkenaan dengan masalah yang diteliti. Penelitian ini diilengkapi dengan pengambilan data kualitatif. Pengambilan data kualitatif digunakan untuk menggali data yang belum terkaji secara mendalam pada saat pengambilan data secara kuantitatif melalui studi dokumentasi dan ceklist observasi. Penelitian ini dilakukan di RSUD Ungaran Kabupaten Semarang. Berkas klaim rekam medis RSUD Ungaran yang dikembalikan oleh verifikator BPJS kesehatan yang disebabkan dispute kode pada bulan Agustus 2018 sebanyak 67 berkas klaim. Metode pengumpulan data dalam penelitian ini meliputi Observasi pada jumlah berkas pending klaim, verifikasi BPJS, dispute kode, deskripsi dan kode Ina CBGs, tarif klaim dan tarif rumah sakit. ceklist observasi analisis resume medis digunakan untuk mengetahui kelengkapan dan konsistensi resume medis, ceklist pedoman koding digunakan untuk akurasi kode. Revisi dan penyelesaian dispute kode dilaksanakan dengan triangulasi data melaului focus group diskusi antara koder, verifikator dan peneliti.

\section{Hasil dan Pembahasan}

\section{Klasifikasi dispute kode berdasarkan kelompok Case-Mix Main Groups (CMG)}

Penelitian ini dilakukan pada 67 berkas klaim yang dikembalikan, adapun klasifikasi berkas klaim yang dikembalikan berdasarkan kelompok Case-Mix Main Groups (CMG).
Tabel 3 : Distribusi frekuensi klasifikasi dispute kode berdasarkan kelompok Case-Mix Main Groups (CMG)

\begin{tabular}{|c|c|c|c|c|}
\hline \multirow{2}{*}{$\mathrm{NO}$} & \multirow{2}{*}{ DESKRIPSI CMG } & \multirow{2}{*}{$\begin{array}{c}\text { KODE } \\
\text { CMG }\end{array}$} & \multicolumn{2}{|c|}{ JUMLAH } \\
\hline & & & $\mathrm{f}$ & $\%$ \\
\hline 1 & $\begin{array}{l}\text { Central nervous } \\
\text { system Groups }\end{array}$ & G & 2 & 2,99 \\
\hline 2 & $\begin{array}{l}\text { Respiratory system } \\
\text { Groups }\end{array}$ & $\mathrm{J}$ & 11 & 16,42 \\
\hline 3 & $\begin{array}{l}\text { Cardiovascular } \\
\text { system Groups }\end{array}$ & I & 2 & 2,99 \\
\hline 4 & $\begin{array}{l}\text { Digestive system Gr } \\
\text { oups }\end{array}$ & $\mathrm{K}$ & 1 & 1,49 \\
\hline 5 & $\begin{array}{l}\text { Hepatobiliary \& } \\
\text { pancreatic system } \\
\text { Groups }\end{array}$ & B & 2 & 2,99 \\
\hline 6 & $\begin{array}{l}\text { Endocrine system, } \\
\text { nutrition \& } \\
\text { metabolism Groups }\end{array}$ & $\mathrm{E}$ & 3 & 4,47 \\
\hline 7 & $\begin{array}{l}\text { Nephro-urinary } \\
\text { System Groups }\end{array}$ & $\mathrm{N}$ & 5 & 7,46 \\
\hline 8 & Deliveries Groups & $\mathrm{O}$ & 7 & 10,44 \\
\hline 9 & $\begin{array}{l}\text { Newborns \& } \\
\text { Neonates Groups }\end{array}$ & $\mathrm{P}$ & 2 & 2,99 \\
\hline 10 & $\begin{array}{l}\text { Myeloproliferative } \\
\text { system \& neoplasms } \\
\text { Groups }\end{array}$ & $\mathrm{C}$ & 8 & 11,94 \\
\hline 11 & $\begin{array}{l}\text { Infectious \& parasitic } \\
\text { diseases Groups }\end{array}$ & A & 24 & 35,82 \\
\hline & Total & & 67 & 100,00 \\
\hline
\end{tabular}

Tabel 3 Berkas klaim berdasarkan klasifikasi kelompok Case-Mix Main Groups (CMG) diketahui bahwa sebagian besar klasifikasi berkas klaim adalah kelompok Case-Mix Main Groups kode A (Infectious and parasitic diseases Groups) sebanyak 24 kasus $(35,82 \%)$, kemudian kelompok Case-Mix Main Groups kode J (Respiratory system Groups) sebanyak 11 kasus $(16,42 \%)$, dan kelompok CaseMix Main Groups kode C (Myeloproliferative system \& neoplasms Groups) sebanyak 8 kasus $(11,94 \%)$.

Berdasarkan hasil penelitian berkas klaim adalah kelompok Case-Mix Main Groups kode A(Infectious and parasitic diseases Groups), dimana kondisi ini sesuai dengan RSUD Ungaran yang merupakan fasilitas kesehatan rujukan tingkat lanjut (FKTRL) dengan klasifikasi tipe C. Sebagian besar jenis kasus yang ditangani oleh rumah sakit adalah jenis kasus ringan yang ditangani oleh dokter spesialis yang tidak memerlukan pemeriksaan penunjang dan prosedur 
tindakan medis dengan menggunakan kelengkapan peralatan medis yang berat atau peralatan medis yang menggunakan teknologi tingkat tinggi seperti halnya rumah sakit dengan klasifikasi tipe B dan A

\section{Gambaran analisis dispute kode diagnosis rumah sakit dengan BPJS Kesehatan}

Tabel 4 : Distribusi frekuensi dispute kode diagnosis oleh BPJS dan rumah sakit

\begin{tabular}{lllc}
\hline \multirow{2}{*}{ NO } & \multicolumn{1}{c}{ KATEGORI } & \multicolumn{2}{c}{ JUMLAH } \\
\cline { 2 - 4 } & \multicolumn{1}{c}{$\mathrm{f}$} & $\%$ \\
\hline 1 & Kode tidak spesifik & 9 & 13,43 \\
\hline 2 & $\begin{array}{l}\text { Kode DU atau kode DS } \\
\text { tidak didukung oleh data } \\
\text { pemeriksaan penunjang }\end{array}$ & 53 & 79,10 \\
\hline 3 & $\begin{array}{l}\text { Kode DS menjadi bagian atau } \\
\text { lanjutan dari kode DU }\end{array}$ & 4 & 5,97 \\
\hline 4 & $\begin{array}{l}\text { Kode pada kondisi diagnosis } \\
\text { suspect }\end{array}$ & 1 & 1,50 \\
\hline & Total & 67 & 100,00 \\
\hline
\end{tabular}

$\overline{\text { Tabel } 4 \text { diketahu dispute kode diagnosis rumah }}$ sakit dan BPJS sebagian besar adalah pada kondisi kode DU atau kode DS tidak didukung oleh data pemeriksaan penunjang sebanyak 53 kasus $(79,10 \%)$

Kondisi kelompok pertama sebagian besar terjadi pada kasus kelompok klasifikasi Case-Mix Main Groups kode A (Infectious and parasitic diseases Groups) pada kode A01.0 (typoid fever) dan pada kelompok klasifikasi Case-Mix Main Groups kode J (respiratory system Groups) pada kode J18.0 (bronchopneumonia unspecified).

Didalam resume medis pasien tercatat diagnosis observasi typoid dengan hasil pemeriksaan sebagai berikut mual $(+)$, muntah $(+)$, nyeri perut $(+)$. Widal tes titer $\mathrm{O}=1 / 160$. Koder menuliskan kode DU A01.0 (typoid fever), kode DU belum bisa ditegakkan karena tidak didukung data pemeriksaan penunjang. Kode DU A01.0 (typoid fever) dapat di tegakkan apabila hasil pemeriksaan uji widal pada minggu pertama dengan hasil titer antibodi $\mathrm{O}>1 / 320$ dan titer antibodi $\mathrm{H}>1 / 640$ (WHO). Sehingga kode DU A01.0 direvisi menjadi kode Z03.8 (Observation for other suspected diseases and conditions), karena sampai akhir episode perawatan belum ada diagnosis spesifik yang ditegakkan, diagnosis yang tercatat dalam resume medis observasi typoid.

Selanjutnya pada kondisi kode tidak spesifik sebanyak 9 kasus $(13,43 \%)$. Ketidakspesifikan kode terjadi pada kelompok klasifikasi Case-Mix Main Groups kode P (Newborns and Neonates Groups) pada kode P21.9 (Birth asphyxia, unspecified) dan kelompok klasifikasi Case-Mix Main Groups kode O (Deleiveries Groups) pada kode O00.9 (Ectopic pregnancy, unspecified) (WHO, ICD-10). Didalam resume medis pasien tercatat diagnosis asfiksia, dengan hasil pemeriksaan bayi baru lahir lemah $(+)$, gerak $(+)$, nagis $(+)$ suhu tubuh 36 derajat Celcius, nilai apgar score 7 . Koder menuliskan kode DU P21.9 (birth asphyxia unspecified), kode DU tidak spesifik tidak sesuai hasil data klinis dimana nilai apgar score 7, sehingga kode direvisi lebih spesifik menjadi P21.1 (Mild and moderate birth asphyxia) Asphyxia with 1-minute Apgar score 4-7 (WHO, ICD-10).Kemudian pada kondisi Kode DS menjadi bagian atau lanjutan dari kode DU sebanyak 4 kasus $(5,97 \%)$.

Kode DS menjadi bagian atau lanjutan dari kode DU pada kelompok klasifikasi Case-Mix Main Groups kode I (Cardiovascular system Groups) pada kode I50.0 (Congestive heart failure)

Pada resume medis tercatat beberapa diagnosis CHF, gagal ginjal dan oedem paru hasil pemeriksaan sebagai berikut keluhan sesak, batuk, nyeri ulu hati, dan mual. Tekanan darah pasien 170/90 mmHg. Pasien dirawat selama 4 hari. Pasien sudah menjalani pemeriksaan EKG dan pemeriksaan rongent ada. Koder menuliskan kode DU I50.0 (Congestive heart failure) dan kode DS J81 (Pulmonary oedema). Kode DS J81 (Pulmonary oedema) tidak dapat ditegakkan sendiri, keadaan edema paru pada pasien $\mathrm{CHF}$ sudah menjadi satu kesatuan pada CHF sehingga tidak perlu ditagihkan lagi sebagai diagnosis sekunder, Penggunaan Kode J81, di-exclude-kan with mention heart disease NOS or heart failure (WHO, ICD-10). Kode DS J81 di exclude karena berdampak terhadap peningkatan severity level dan berdampak terhadap grouping yang mengakibatkan kenaikan data billing.

Paling sedikit adalah pada kondisi diagnosis suspect yaitu sebanyak 1 kasus (1,50\%). Kode pada kondisi suspect pada kelompok klasifikasi Case-Mix Main Groups kode C (Myeloproliferative system and neoplasms Groups). Pada resume medis tercatat diagnosis dugaan neoplasma ganas cervix, sampai akhir episode perawatan diagnosis belum ditegakkan. Koder menuliskan kode DU C53.9 (Malignant neoplasm of cervix uteri, unspecified). Kode DU C53.9 (Malignant neoplasm of cervix uteri, unspecified) belum dapat ditegakkan karena tidak 
didukung data pemeriksaan penunjang, sehingga kode DU direvisi dengan kode Z03.1 (Observation for suspected malignant neoplasm).

Jika diagnosis yang lebih spesifik belum ditegakkan sampai akhir episode perawatan atau tidak ada penyakit atau cedera pada saat dirawat yang bisa dikode, maka kode dari Bab XVIII dan XXI dapat digunakan sebagai kode diagnosis utama (lihat juga Rules MB3 dan MB5). Kategori Z03.- (observasi dan evaluasi medis untuk penyakit dan kondisi yang dicurigai) digunakan untuk diagnosis "suspek" yang dapat dikesampingkan setelah dilakukan pemeriksaan lanjutan. (PMK 76 tahun 2016).

\section{Gambaran penyelesaian dispute kode berdasarkan reseleksi kode}

Jika beberapa kondisi yang tidak bisa dikode bersamaan tercatat sebagai diagnosis utama, maka dilakukan reseleksi kode dengan memilih salah satu kondisi yang menunjukkan bahwa satu di antaranya adalah diagnosis utama pada pasien yang selama episode perawatan diberikan asuhan dan menghabiskan sumber daya paling banyak selama episode perawatan, selain itu juga dapat dipilih sesuai dengan dokter penanggung jawab pasien (DPJP) yang menangani pasien tersebut.

Didalam resume medis tercatat lebih dari satu kondisi utama, sehingga untuk menentukan kode diagnosis utama, koder melaksanakan reseleksi kode rule MB2, kondisi ini yang seringkali membuat kesalahan atau ketidakakuratan kode. Karena pada saat menentukan kode diagnose utama harus benar-benar menentukan kode yang akurat dan presisi.

Hal ini membutuhkan kemampuan koder dalam menganalisis resume medis dan data-data penunjang lainnya di dalam berkas rekam medis untuk mendukung penegakan kode diagnosis utama.

Reseleksi rule MB4 (kespesifikan) adalah kondisi dimana diagnosis yang tercatat sebagai diagnosis utama menguraikan suatu kondisi secara umum, sedangkan suatu istilah yang bisa memberikan informasi yang lebih tepat mengenai tempat atau bentuk kondisi tersebut tidak tercatat. Untuk menentukan diagnose utama dilakukan reseleksi kode dengan pedoman rule MB4. Apabila sampai akhir periode perawatan pasien dan didalam resume medis pasien tercatat diagnosis yang masih merupakan kondisi umum, maka untuk menentukan kode diagnose utama dipilih kode yang lebih spesifik, disesuaikan dengan hasil analisis resume medis dan hasil pemeriksaan klinis dan data penunjang dan di sesuaikan dengan pedoman koding yaitu ICD-10 dan ICD-9 CM. Hal ini membutuhkan kemampuan koder dalam menganalisis resume medis dan datadata penunjang lainnya di dalam berkas rekam medis untuk memilih kode yang lebih spesifik.

Kode kondisi supect adalah kondisi dimana jika diagnosis yang lebih spesifik belum ditegakkan sampai akhir episode perawatan atau tidak ada penyakit atau cedera pada saat dirawat yang bisa dikode maka kode dari Bab XVIII dan XXI dapat digunakan sebagai kode diagnosis utama.

Sesuai dengan PMK 76 tahun 2016 tentang pedoman INA-CBG dalam pelaksanaan JKN bahwa Kategori Z03.- (observasi dan evaluasi medis untuk penyakit dan kondisi yang dicurigai) digunakan untuk diagnosis "suspek" yang dapat dikesampingkan setelah dilakukan pemeriksaan lanjutan.

\section{Simpulan}

Sebagian besar berkas klaim yang dikembalikan adalah kasus dengan klasifikasi kelompok CaseMix Main Groups (CMG) kode A (Infectious and parasitic diseases Groups) sebanyak 35,82\%. Dan sebagian besar penyelesaian berkas klaim pengembalian karena dispute kode adalah dengan reseleksi kode rule MB2 sebanyak 59,70\%

Dalam rangka menurunkan angka berkas pengembalian klaim BPJS, maka disarankan

1. Bagi tenaga koder

Didalam menentukan kode hendaknya selalu membaca kembali dan mengikuti kaidah-kaidah penentuan kode sesuai dengan ketentuan yang telah ditetapkan.

2. Bagi tenaga medis

Sumber data untuk mengkode INA-CBG berasal dari resume medis dan apabila diperlukan dapat dilihat dalam berkas rekam medis, sehingga tenaga medis perlu memahami bahwa kelengkapan dan kekonsistensian dalam pengisian rekam medis sangat dibutuhkan untuk menghasilkan kode yang akurat.

3. Kepala instalasi rekam medis

Kepala instalasi rekam medis melalaui komite medis mengusulkan adanya sosialisasi kepada tenaga medis, tenaga koder, dan verifikator 
terkait adanya pedoman-pedoman terkini INACBG dalam implementasi JKN

\section{Daftar Pustaka}

Hatta, Gemala.R. (2013). Pedoman Manajemen Informasi Kesehatan di sarana pelayanan kesehatan. Jakarta: Penerbit Universitas Jakarta

Kepmenkes Nomor 377 Tahun 2007 tentang Standar Profesi Perekam Medis dan Informasi Kesehatan. Jakarta: Menkes RI

Mathis R.L dan Jackson J.H, 2002. Manajemen Sumber Daya Manusia, Jakarta : Salemba Empat

National Center for Health Statistics. 2008. International Classification of Disease, Tenth Revision (ICD-10). Diunduh : 23 Februari 2016

Internet : http://www.cdc.gov/nchs/about/major/dvc/ icd10des.htm.

Notoatmodjo, S. (2012). Metodologi Penelitian Kesehatan. Jakarta: Rineka Cipta

Olivia, Firza. (2016). Analisis Administrasi Klaim Jaminan Kesehatan Nasional Rawat Jalan RSUD Kota Semarang Tahun 2016. Semarang : Jurnal Kesehatan Masyarakat Universitas Diponegoro.

Oryza, Rizki. (2015). Identifikasi Kelengkapan Informasi dan Keakuratan Kode Rekam medis Terkait Penentuan Tarif Biaya Pasien BPJS di RSUD Pandan Arang Boyolali. Surakarta : Universitas Muhammadiyah Surakarta.

Peraturan Menteri Kesehatan Republik Indonesia Nomor 27 Tahun 2014 tentang Petunjuk Teknis Sistem INA-CBG's. 2014. Jakarta: Menkes RI

Peraturan Menteri Kesehatan Republik Indonesia Nomor 36 Tahun 2015 tentang Pencegahan Kecurangan (Fraud) dalam pelaksanaan program JKN pada SJSN. 2015. Jakarta: Menkes RI

Peraturan Menteri Kesehatan Republik Indonesia No. 269/Menkes/SK /III/2008 tentang Rekam Medis. 2008. Jakarta: Menkes RI
Peraturan Menteri Kesehatan Republik Indonesia No. 290/Menkes/Per/III/2008 tentang Persetujuan Tindakan Kedokteran. 2008. Jakarta: Menkes RI

Permenkes RI No. 76 th 2016 tentang Pedoman INA CBGs (Indonesian Case Base Groups) dalam pelaksanaan JKN (Jaminan Kesehatan Nasional)

Surat Edaran Menkes HK.03.03/518 Th 2016 tentang Pedoman Penyelesaian Permasalahan klaim INA-CBGs

SK Menkes RI No. 50/MENKES/SK/I/1998. Pemberlakuan Klasifikasi Statistik Internasional Mengenai Penyakit Revisi keSepuluh tertanggal 13 Januari 1998

Terry, G.R. Penelaahan Buku Principles of Management. Balai Lektur Mahasiswa UNPAD. Bandung. 1980

Undang-Undang Republik Indonesia Nomor 24 Tahun 2011 tentang BPJS

Undang-undang Republik Indonesia Nomor 36 Tahun 2009 tentang Kesehatan

Undang-undang Republik Indonesia Nomor 36 Tahun 2014 tentang Tenaga Kesehatan

Undang-undnag Republik Indonesia Nomor 40 Tahun 2004 tentang SJSN

World Health Organization, 2004. International Statistical Classification od Dissease and Related Health Problems Tenth Revision Volume 2 second edition. Geneva: World Health Organization

www.indonesian-publichealth.com, tentang UnsurUnsur Managemen diakses pada tanggal 02 Februari 2018

www.hakayuci.com tentang Sistem kodefikasi, diakses pada tanggal 02 Februari 2018

WHO. ICD-10 volume1,2,3 revisi ke 10 (International Statistical Clasification of Diseases and Related Health Problems $10^{\text {th }}$ Revision Volume 1,2,3). 2010

WHO. ICD-9CM Volume 3 (The International Clasification of Diseases-Clinical Modification $9^{\text {th }}$ Revision Volume 3).2010 